\title{
EVALUATION OF ANALGESIC ACTIVITY OF ROOTS OF PICRORHIZA KURROA
}

\author{
*Shid Rupali L., Soma B. Raha, Shid Santosh L. \\ Rajgad Dyanpeeth's College Of Pharmacy Bhor, Pune, India- 412107 \\ *Corresponding Author's Email.ID: rupalishid23@gmail.com
}

\begin{abstract}
Methodology: The selected drug from the authentic literature is in form of dried roots of Picrohiza kurroa belonging to family scrophulariaceae. Analgesic activity of root powder is extracted with alcohol for 7 days. The extracts in these dose levels of $250 \mathrm{mg} / \mathrm{kg}, 500 \mathrm{mg} / \mathrm{kg}$ were tested. The analgesic activity was studied by using the Hot plate and Acetic acid inducedwrithing method in albino mice of either sex. The writhing are measured within $10 \mathrm{~min}$.

Results: The $500 \mathrm{mg} / \mathrm{kg}$ drug of picrorhiza kurroa having similar effect to the standard drug pentazocin at $1 / 2$ hrs.pentazocin is agonist-antagonist type of analgesic drug.in hot plate method the $500 \mathrm{mg} / \mathrm{kg}$ drug of picrorhiza kurroa is effective at the $1 / 2 \mathrm{hrs}$ than the $250 \mathrm{mg} / \mathrm{kg}$

Conclusions: Dose effective of ethanolic extract of picrorhiza kurroa $500 \mathrm{mg} / \mathrm{kg}$. by Hot plate method and Acetic acid induced writhing method.
\end{abstract}

Keywords: Picrorhiza kurroa, Analgesic activity, Hot Plate, Acetic acid.

\section{INTRODUCTION:-}

1.1.Algesia defined unpleasant sensation usually evoked by an external or internal noxious stimulus.

Pain is a warning signal and primarily protective in nature but causes discomfort. It is most important symptom that brings the patient to the physician. Excessive pain may be unbearable and causes other effects sinking sensation, apprehension, sweating, nausea, palpitation, rise or fall in BP, tachypnoea. Analgesic relieves pain as symptoms without affecting its causes. They are used when noxious stimulus can not removed or adjuvant to more etiological approach to the pain. (Ader, R. 1997).

\subsection{Pain Pathway :}

Pain transduction and perception is extensive and complex, involving fundamental biological events at multiple levels of the nervous system. We focuse on the place where sensation of pain is initiated, the primary afferent nociceptors. Nociceptors are a subpopulation of primary sensory neurons that are activated by noxious stimuli, i.e.stimuli that can produce tissue damage. Compelling evidence suggests that plasticity in nociceptors contributes substantially to the increased pain one feels in the presence of injury. Plasticity in nociceptors is critical for both the development and maintenance of plasticity in the central nervous system. That many receptors and ion channels recently identified are found specifically in nociceptors makes these proteins very good targets for eliminating pain without inducing side effects. Finally the accessibility of the peripheral nervous system makes nociceptors a logical target for the development of novel therapeutic interventions.Painful stimuli such as intense heat activate the peripheral terminals of nociceptors. Action potentials are transmitted along the afferent axons to the spinal cord. The central terminals of IB 4 - negative unmyelinated nociceptors synapse in lamina I and outher lamina II, whereas IB 4 - positive unmyelinated nociceptors terminate in inner lamina II. By means of chemical transmission, nociceptors activate spinal neurons that send axons across the spinal cord and up fiber tracts and terminate in the medulla, midbrain, and thalamus. Thalamic neurons project to regions of the cortex including the somatosensory cortex.Two key lines of discovery have been (i) molecular / cellular transduction mechanisms and (ii) neuronal plasticity (Amanzio, M. et al 1999)

\subsection{Molecular / Cellular Mechanisms}

Elegant molecular genetic studies conducted in the past few years have now enabled us to identify specific molecules that are involved in the processes of pain transduction. A giant step forward came with the identification of proteins called vanilloid receptors, which allow us to detect noxious heat. The VR 1 protein is a heat transducer because it converts thermal energy into an electrical signal (action potentials) that is sent to the central nervous system, enabling us to detect a stimulus as painfully hot. Without the VR 1 receptor, one does not effectively detect noxious heat, particularly in the setting of inflammation. Recently basic pain researchers have identified a number of transduction molecules that will clearly be key targets in developing pioneering pain therapies' (Burns, J. W. et al. 2009).

\subsection{Neuronal Plasticity}

Plasticity is a term used to refer to changes that occur in the established nervous system. Changes in neuronal structure, connections between neurons, and alterations in the quantity and properties of neurotransmitters, receptors, and ion channels can ultimately result in increased functional activity of neurons in the pain pathway. Conversely, plasticity can decrease the body's own pain inhibitory systems, resulting ultimately in increased pain. Injury, inflammation, and disease can all cause neuronal plasticity and increased pain by means of increased excitatory or decreased inhibitory mechanisms. Plasticity can result in short - term changes those last minutes to hours or long - term changes which may be permanent. 
Analgesic : a drug that selectively relieve pain by acting in the CNS or on peripheral pain mechanism without significant altering consciousness. (Ader, R. 1997).

1.6.plant introduction. (Anandan R, Devaki T 1999), (Anandan R et al 2000).

\section{Botanical Name-Picrorhiza kurroa}

\section{Family-Scrophulariaceae}

\section{Description of plant:}

Leaves - Flat, oval \& sharply serrated

Flowers - White or pale purple born on tall spike.

Fruits $-1 / 2$ inch long and is oval in shape.

Rhizomes - deep qreyish brown in colour, externally white, blackish internally, with whitish wood.

Odour - Slight and unpleasent.

Taste - Bitter.

Size -3 to $5 \mathrm{~cm}$. in length and 0.5 to $1 \mathrm{~cm}$ in diameter

shape - cylindrical pieces with longitudinal wrinkles and annulations at the tip.

Features - Conical, buds and stem along with the roots also constitute the drug. The roots are longitudinally wrinklead with transverse cracks, Roots are grey to brown in colour.

\section{Chemical constituent:-}

kutkin- kutkoside, picroside-irridoid, glycoside, picrosideI,II,III, apocynin, androsin, cucurbitacin, D-mannitol, vanillic acid, some steroids, glucose, wax, cathartic acid.

\section{Medicinal Uses:}

Bitter Stomachic, Digestive condition gastric irritant, cathartic, choagogue,

emetic, abortifacient, cardiotonic Anti - Asthmatic activity, liver protective, hepatotoxic effect, anti - oxidant, anti - inflmmatory immune system requlator, bitter, Carminative, anticholestatic, laxative, liver conditions.

OBJECTIVE: To Perform Analgesic Activity Of Roots Of Picrorhiza Kurroa by using Hot Plate and acetic acid induced writhing method

\section{MATERIAL AND METHODS}

\subsection{Plant material:}

Roots of Picrorhiza kurroa are collected from Mumbai and authenticated from Agharkar Research Institute and the college certificate is submitted to use.

Preparation of extract- The air dried roots were powdered. crude powder $(25 \mathrm{~g})$ was soaked in $100 \mathrm{ml}$ of $95 \%$ ethnol for 7 days with intermittent shaking on $8^{\text {th }}$ day, the whole material was collected and concentrated under reduced pressure. The residual solvent was evaporated and the solid blackish-brown mass obtained (4.5gm.) was kept under vaccum.

percentage yield of the dried extract is $18 \%$.

During use the dried material after weighing was placed in mortar-pestle to which $2 \% \mathrm{w} / \mathrm{v}$ of gum acacia was added and macerated with double distilled water. It was tranferred to small tube and the volume was made up as required for different experiment.

\subsection{Qualitative chemical identification tests:-}

The extract of Picrorhiza kurroa Roots was subjected to qualitative chemical tests to detect the presens of phytoconstituents as follows:-

\section{Tests for carbohyhydrats :-}

Molish Test :- Treated the extract solution with few drops of alcholic a-napthol. Added $0.2 \mathrm{ml}$ of concentrated Sulfuric acid slowly through the side of the test tube, purple to violet color ring appears at the junction.

Benedict's Test :- Treated the extract solution with few drops of Benedict's reagent (alkaline solution containing cupric citrate complex) and upon boiling on the water bath, reddish brown precipitate forms if reducing sugar are present.

Barfoed's Test :- General test for monosaccharideHeated the test tube containing $1 \mathrm{ml}$ reagent and $1 \mathrm{ml}$ of extract solution in beaker of boiling water if red cuprous oxide is formed within two minutes, a monosaccharide is present. Disaccharide on prolonged heating (about 10 minutes) may also cause reduction, owing to partial hydrolysis to monosaccharide.

Fehling's Test :- Equal volume of fehling's A (Copper sulphate in distilled water) and fehling's B (Potassium tartarate and Sodium hydroxide in distilled Water) reagents were mixed along with few drops of extract solution, boiled, a brick red precipitate of cuporus oxide forms, if reducing sugar are present.

Caramelisation :- Carbohydrates when treated with strong sulfuric acid, they under go charring with the dehydration along with burning sugar smell.

Tollen's Test :- To 100mg of extract added $2 \mathrm{ml}$ of Tollen's reagent, a silver mirror obtained inside the wall of the test tube, indicates the presence of aldose sugar.

Bromine Water Test :- It gets decolorized by aldose but not by the ketose, because bromine water oxidizes selectively the aldehyde group of carboxylic group, giving rise to general class of compounds called aldonic acid.

\section{Tests for steroids :-}

Libermann-Burchard Test :- Extract treated with few drops of acetic unhydride, boiled and cooled, concentrated sulphuric acid is added from the side of the test tube, show brown at the junction of two layers and the upper layer turns green which shows the presence of steroid and

Salkowski Test :- Treated extract in chloroform with few drops of concentrated sulphuric acid, shake well and allow to stand for sometimes, red color appears in the lower layer indicates the presence of Steroid and formation of yellow colored lower layer indicates the presence of Triterpenoids.

\section{Tests for glycosides :-}

Test I :- Extracted 200mg of the drug by warming in the test tube with $5 \mathrm{ml}$ of dilute $(10 \%)$ sulphuric acid on a water bath at $100^{\circ} \mathrm{C}$ for two minutes, centrifuged or 
filtered, pipette out supernatant or filtrate. Neutralized the acid extract with $5 \%$ solution of sodium hydroxide (noting the volume of $\mathrm{NaOH}$ added). Added $9.1 \mathrm{ml}$ of Fehling's solution $\mathrm{A}$ and $\mathrm{B}$ until alkaline (test with $\mathrm{pH}$ paper) and heated on water bath for few minutes. Noted the quantity of red precipitate formed and compared with that formed in Test II.

Test II :- Extracted 200mg of the drug sing $5 \mathrm{ml}$ of the dilute $(10 \%)$ sulphuric acid and boiled on water bath. After boiling added equal volume of water to the volume of $\mathrm{NaOH}$ used in the above test. Added $0.1 \mathrm{ml}$ Fehling's A and B until alkaline (red litmus changes to blue) and heated on water bath for two minutes. Noted the quantity of the red precipitate formed.

Compared the precipitate of Test II with Test I. If the precipitate in Test-II is greater than in Test-I, then Glycoside may be present. Since Test-I represent teh amount of free reducing sugar already present in the crude drug, where as Test-II represent the Glycoside after acid hydrolysis.

Test for free sugar:- After complete removal of free sugar, the extract was hydrolyzed With mineral acid and then tested for the glycon and aglycone moieties.

Raymond's Test :- Test solution when treated with dinitrobenzene in hot methonolic alkali, gives violet color.

Legal's Test:- Treated the extract with pyridine and added alkaline sodium nitroprusside solutsion, blood red color appears.

Bromine Water Test:- Test solution when treated with bromine water gives yellow precipitate.

\section{Tests for tannines :-}

Gelatin Test :- Extract solution with $1 \%$ gelatin solution containing $10 \%$ sodium chloride gives white precipitate.

Ferric Chloride Test :- Extract solution gives blue-green color with Fecl3. (with ferric salts, gallotannins and ellagitannins give bluish-black color and precipitates, and condensed tannins gives greenish-precipitate).

Vanillin Hydraochloride Test :- Extract solution when treated with few drops of Vanillin Hydrochloride reagent gives purple and red color. (Test only for condensed Tannins.).

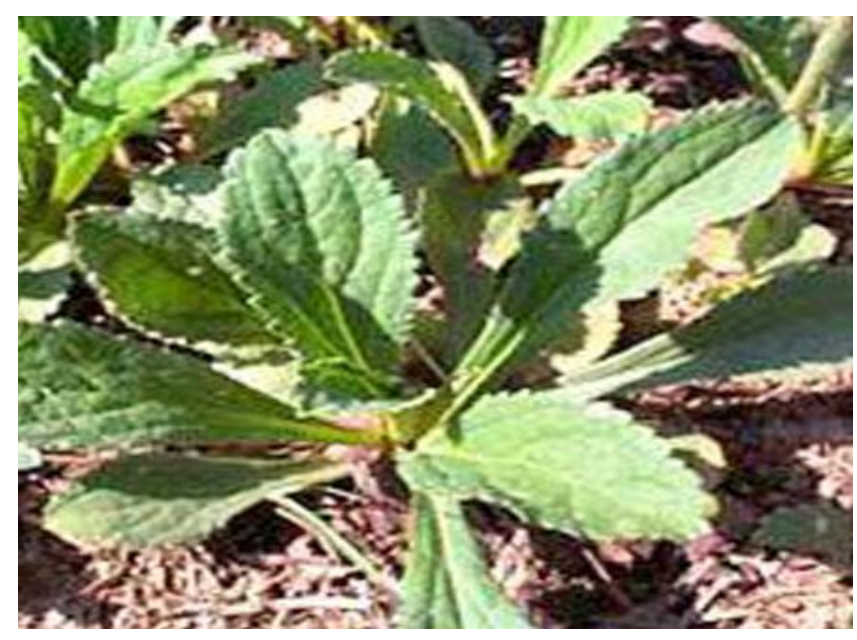

Figure 1: Plant of Picrorhiza kurrooa

\subsection{Animal study}

\subsubsection{Animals :-}

Albino mice of either sex $(20-22 \mathrm{~g})$ were obtained from animal house, Department of Pharmacology R.D.College of Pharmacy Bhor.

These animals were used for the acute toxicity and analgesic activity. The animal were stabilized for 1 week. They were maintained in standard condition at room temperature of $60 \pm 5 \%$ relative humidity and $12 \mathrm{hr}$ light dark cycle and are housed in standard metal cases.

\section{4..Methods:-}

\subsubsection{Hot plate method.}

Drugs were tested in mice using Hot plate. Animals are divided into four groups each containing six animals.

Group I served as control received only vehicle (Gum acacia)

Group II received extract of roots $(250 \mathrm{mg} / \mathrm{kg})$

Group III received extract of roots $(500 \mathrm{mg} . / \mathrm{kg})$

Group IV served as standard that received pentazocin (10mg/kg)

-The basal reaction time was observed by hind paw licking and jump response in animals when placed on the hot plate maintained at constant temperature $\left(55^{\circ} \mathrm{c}\right)$

-The reaction time was again noted at $1 / 2,1,2,3,4 \mathrm{hrs}$ after the treatment.

Calculated mean of time and from which the latency period is calculated.

\subsubsection{Acetic acid induced writhing method:-}

Animals are divided into four groups each containing six animals.

Group I served as control received vehicle and placed them individuly under glass and jar for observation.as well as the number of animals showing such response during a period of $10 \mathrm{~min}$.

Group II recevied extract of roots $(250 \mathrm{mg} / \mathrm{kg})$.

Group III recevied extract of roots $(500 \mathrm{mg} / \mathrm{kg})$.

Group IV were administered Ibuprofen 15 min. after acetic acid administration.

Noted the onset of wriths, recorded the number of abdominal contractions ,trunk twist response and extention of hind limbs as well as number of animals showing such response during a period of $10 \mathrm{~min}$.

\section{Results:}

Table 1: Qualitative Chemical Analysis Of Extract Of Picrorhiza Kurroa.

\begin{tabular}{|l|c|}
\hline Phytoconstituents & Alcoholic Extract \\
\hline Carbohydrate & Present \\
\hline Glycoside & Present \\
\hline Steroids & Present \\
\hline Triterpenoids & Present \\
\hline Proteins and Amino acid & Present \\
\hline
\end{tabular}


The Extract of picrorhia kurroa contains and amino acids.

Carbohydrte,glycoside,steroids, Triterpenoids and proteins

Table 2: Results of Acetic Acid Induced Writhing Model (Number of writhings during a period of 10 min.)

\begin{tabular}{|c|c|c|c|c|}
\hline $\begin{array}{c}\text { Sr. } \\
\text { No. }\end{array}$ & Control & Standard & $250 \mathrm{mg} / \mathrm{kg}$ & $500 \mathrm{mg} / \mathrm{kg}$ \\
\hline 1 & 13 & 3 & 12 & 7 \\
\hline 2 & 13 & 4 & 12 & 8 \\
\hline 3 & 15 & 3 & 10 & 8 \\
\hline 4 & 16 & 5 & 11 & 7 \\
\hline 5 & 14 & 3 & 12 & 6 \\
\hline 6 & 15 & 4 & 10 & 7 \\
\hline
\end{tabular}

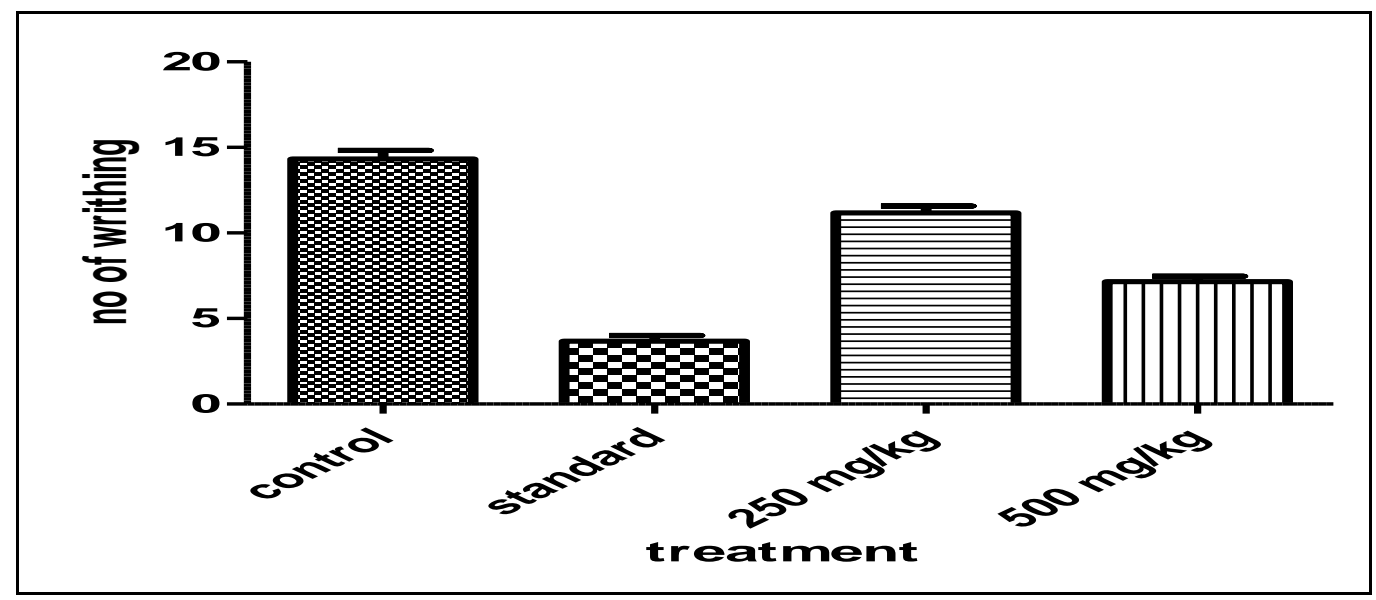

Figure 2: Acetic Acid Induced Writhing Model (Number of writhings during a period of 10 min.of control,standard,250mg/kg and $500 \mathrm{mg} / \mathrm{kg}$ extract)

\begin{tabular}{|l|l|l|l|l|}
\hline Dunnett's Multiple Comparison Test & Mean Diff. q & $\begin{array}{l}\text { Significant? P } \\
<0.05 ?\end{array}$ & Summary & $95 \%$ CI of diff \\
\hline control vs standard & 10.7 & 19.3 Yes & $* * *$ & 9.26 to 12.1 \\
\hline control vs $250 \mathrm{mg} / \mathrm{kg}$ & 3.17 & 5.73 Yes & $* * *$ & 1.76 to 4.57 \\
\hline control vs $500 \mathrm{mg} / \mathrm{kg}$ & 7.17 & 13 Yes & $* * *$ & 5.76 to 8.57 \\
\hline
\end{tabular}

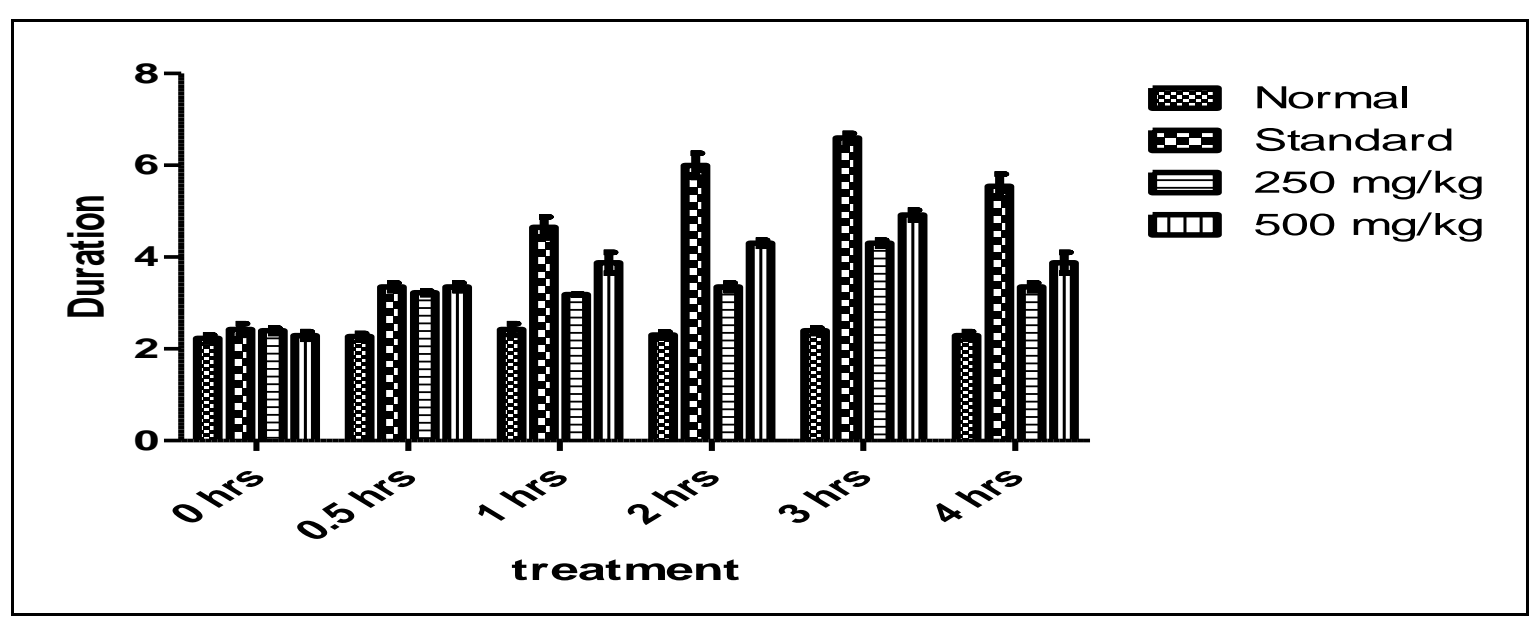

Figure 3: Hot Plate Method (hind paw licking and jump response noted at 1/2, 1, 2, 3, 4 hrs after the treatment of Normal,Standard,250 mg/kg and $500 \mathrm{mg} / \mathrm{kg}$ extract) 
Table 3: Results of Hot Plate Method (hind paw licking and jump response noted at 1/2, 1, 2, 3, 4 hrs after the treatment)

\begin{tabular}{|l|l|l|l|l|l|}
\hline Sr.No. & Time & Control & $250 \mathrm{mg} / \mathrm{kg}$. & $500 \mathrm{mg} / \mathrm{kg}$ & Standard \\
\hline 1 & $0 \mathrm{hr}$. & 2.23 & 2.39 & 2.29 & 2.42 \\
\hline 2 & $0.5 \mathrm{hr}$. & 2.26 & 3.22 & 3.35 & 3.35 \\
\hline 3 & $1 \mathrm{hr}$. & 2.42 & 3.18 & 3.87 & 4.64 \\
\hline 4 & $2 \mathrm{hr}$. & 2.30 & 3.35 & 4.30 & 6.00 \\
\hline 5 & $3 \mathrm{hr}$. & 2.82 & 4.30 & 5.21 & 6.59 \\
\hline 6 & $4 \mathrm{hr}$. & 2.29 & 3.35 & 3.87 & 5.54 \\
\hline
\end{tabular}

\begin{tabular}{|c|c|c|c|}
\hline Source of Variation & $\begin{array}{c}\text { \% of total Variation } \\
\text { (P value) }\end{array}$ & P value Summary & Significant ? \\
\hline Interaction & $17.58<0.0001$ & $* * *$ & Yes \\
\hline Column Factor & $46.94<0.0001$ & $* * *$ & Yes \\
\hline Row Factor & $30.12<0.0001$ & & Y \\
\hline
\end{tabular}

\section{DISCUSSION}

$>$ The present study includes systematic morphological study and Analgesic activity.

$>$ In this present study analgesic effect of Picrorhiza kurroa was evaluated.

$>$ Analgesic effects of Picrorhiza kurroa were evaluated using chemical and thermal models of nociception. In acetic acid induced writhing model Picrorhiza kurroa has shown significant inhibition of the writhing syndrome in a increased dose dependent manner. Acetic acid induces pain by the releas endogenous mediators of pain such as prostacyclin via COX cycloxygenase. This model which may effective to inhibit COX. our results shows Picrorhiza kurroa has peripheral analgesic property to compare to enmethaced.Picrorhiza kurroa at $500 \mathrm{mg} / \mathrm{kgbody}$ wt. was more effective at inhibiting acetic acid inducing pain.

$>$ It was found that $500 \mathrm{mg} / \mathrm{kg}$. dose of picrorhiza kurroa roots is effective as Analgesic.

$>$ Hot plate method is a thermal method of analgesic activity.

$>$ It shoos effective analgesic activity at $1 / 2 \mathrm{hr}$.
$>$ The $500 \mathrm{mg} / \mathrm{kg}$ drug of picrorhiza kurroa having similar effect to the standard drug pentazocin at $1 / 2$ hrs.pentazocin is agonist-antagonist type of analgesic drug.in hot plate method the $500 \mathrm{mg} / \mathrm{kg}$ drug of picrorhiza kurroa is effective at the $1 / 2$ hrs than the $250 \mathrm{mg} / \mathrm{kg}$.

\section{CONCLUSION:}

In this present study analgesic effect of Picrorhiza kurroa was evaluated By using Hot Plate and Acetic acid induced writhing method from which it is concuded that $500 \mathrm{mg} / \mathrm{kg}$. dose of picrorhiza kurroa roots is effective as Analgesic.Hot plate method is a thermal method of analgesic activity.It shoos effective analgesic activity at $1 / 2$ $\mathrm{hr}$.The $500 \mathrm{mg} / \mathrm{kg}$ drug of picrorhiza kurroa having similar effect to the standard drug pentazocin at $1 / 2 \mathrm{hrs}$.pentazocin is agonist-antagonist type of analgesic drug.in hot plate method the $500 \mathrm{mg} / \mathrm{kg}$ drug of picrorhiza kurroa is effective at the $1 / 2 \mathrm{hrs}$ than the $250 \mathrm{mg} / \mathrm{kg}$.

\section{ACKNOWLEDGMENT}

I extend sincere gratitude towards Mrs. Soma Raha. Who not only guide me throughout my T.Y.B.Pharm project, but also motivated me to work better and harder..I am also thankful to My Family And All My Friends 


\section{REFERENCES:}

1)Ader, R,Processes underlying the placebo effects: The preeminence of Conditioning, The Journal of Pain: Pain Forum. ,1997, 6(1),5658.

2)Amanzio, M. and F. Benedetti ,Neuropharmacological dissection of placebo analgesia: expectation-activated opioid systems versus conditioning-activated specific subsystems, J Neurosci ,1999,19(1),484-494.

3)Brown, C. A., B. Seymour,Modulation of pain ratings by expectation and uncertainty: Behavioral characteristics and anticipatory neural correlates,Pain,2008,135(3),240-250.

4)Burns, J. W., S. Bruehl,Endogenous opioids may buffer effects of anger arousal on sensitivity to subsequent pain,Pain, 2009,146(3),276-282.

5)Bruynzeel A M, Abou El, Hassan MA, Schalkwijk C, Berkhof J, Bast A,Niessen HW, Van der Vijgh WJ,Anti-inflammatory agents and monoHER protect against DOX-induced cardiotoxicity and accumulation of CML in mice, Br. J. Cancer,2007,96,937-943.

6)Bryant J, Picot J, Levitt G, Sullivan I, Baxter L, Clegg,A Cardioprotection against the toxic effects of anthracyclines given to children with cancer: a systematic review. Health Technol. Assess, 2007,11,1-102.

7)Catala A, Zvara A, Puskas LG, Kitajka K,Melatonin-induced gene expression changes and its preventive effects on adriamycininduced lipid peroxidation in rat liver,J. Pineal Res, 2007,42,43-49.

8)Daosukho C, Chen Y, Noel T, Sompol P, Nithipongvanitch R, Velez JM,Oberley TD, St Clair DK,Phenylbutyrate, a histone deacetylase inhibitor, protects against adriamycin-induced cardiac injury. Free Radic,Biol. Med,2007,42,1818-1825.

9)Deepa PR, Varalakshmi P,Protective effect of low molecular weight heparin on oxidative injury and cellular abnormalities in adriamycin-induced cardiac and hepatic toxicity, Chem. Biol. Interact, 2003,146,201-210.

10) Anandan R, Devaki T,Hepatoprotective effect of Picrorhiza kurroa on tissue defence system in D-galactosamine-induced hepatitis in rats,Fitoterapia,1999,70,54-57.

11) Anandan R, Rekha RD, Devaki T, Kumar MS,Biochemical studies on the protective effects of Picrorhiza kurroa in experimentally induced hepatitis in rats. J. Clin. Biochem. Nutr.,2000,29: 09-17.

12) Anandan R, Rekha RD, Devaki T,Protective effect of Picrorhiza kurroa on mitochondrial glutathione antioxidant system in Dgalactosamine- induced hepatitis in rats. Curr. Sci.,1999,761543-1545 